\title{
Beneficial Role of Low-Intensity Laser Irradiation on Neural $\beta$-tubulin III Protein Expression in Human Bone Marrow Multipotent Mesenchymal Stromal Cells
}

\author{
Valéria Ferreira-Silva ${ }^{1,2} \cdot$ Fernando L. Primo ${ }^{3}$ - Munira M.A. Baqui ${ }^{4} \cdot$ Danielle A.R. Magalhães $^{2} \cdot$ Maristela D. Orellana $^{2} \cdot$ \\ Andrielle Castilho-Fernandes ${ }^{1} \cdot$ Mario C. Cruz ${ }^{5}$. Niehls O. S. Câmara ${ }^{5} \cdot$ Dimas T. Covas $^{2,6} \cdot$ Antonio C. Tedesco $^{1}$
}

Published online: 13 February 2018

๑) Springer Science+Business Media, LLC, part of Springer Nature 2018

\begin{abstract}
The purpose of the present study was to evaluate the neural protein expression pattern of human multipotent mesenchymal stromal cells (hMSCs) treated with forskolin (free-form/FF). The study investigated forskolin's capacity to enhance intracellular levels of cyclic adenosine monophosphate (cAMP) by activating adenylate cyclase and probably by inducing neuron-like cells in vitro. In addition, because nanotechnology is a growing field of tissue engineering, we also assessed the action of a new system called the nanostructured-forskolin (NF) to examine the improvement of drug delivery. Afterwards, the cells were submitted to low-level laser irradiation to evaluate possible photobiostimulatory effects. Investigations using the immunofluorescence by confocal microscopy and Western blot methods revealed the expression of the neuronal marker $\beta$-tubulin III. Fluorescence intensity quantification analysis using INCell Analyzer System for $\beta$-tubulin III was used to examine significant differences. The results showed that after low-level laser irradiation exposure, there was a tendency to increase the $\beta$-tubulin III expression in all groups, as expected in the photobiostimulation process. Notably, this process induced for irradiation was more pronounced in irradiated nanoforskolin cells (INF) compared to non-irradiated free-forskolin control cells (NFFC). However, there was also an increase in $\beta$-tubulin III protein expression in the groups: irradiated nanocontrol cells (INC) compared to non-irradiated free-forskolin control cells (NFF) and after treatment with non-irradiated freeforskolin (NFF) and non-irradiated nanoforskolin (NNFC). We concluded that the methods using low-level laser irradiation and/or nanoparticles showed an up-regulation of neural-protein expression in hMSCs that could be used to facilitate cellular therapy protocols in the near future.
\end{abstract}

Keywords Low-intensity laser irradiation $\cdot$ Nanotechnology $\cdot$ Forskolin $\cdot$ Nano-drug delivery $\cdot \beta$-Tubulin III $\cdot$ Multipotent mesenchymal stromal cells

Antonio C. Tedesco

atedesco@usp.br

1 Department of Chemistry, Centre of Nanotechnology and Tissue Engineering-Photobiology and Photomedicine Research Group, Faculty of Philosophy, Sciences and Letters of Ribeirão Preto, University of São Paulo, Ribeirão Preto 14040-901, Brazil

2 Centre for Cell Therapy and Regional Blood Centre, National Institute of Science and Technology in Stem Cell and Cell Therapy, Medical School, University of São Paulo, Ribeirão Preto 14051-140, Brazil
3 Department of Bioprocess and Biotechnology, School of Pharmaceutical Sciences, São Paulo State University (UNESP), Araraquara 14800-903, SP, Brazil

4 Department of Cell and Molecular Biology and Pathogenic Bioagents, Medical School, University of São Paulo, Ribeirão Preto 14049-900, Brazil

5 Institute of Biomedical Science, Department of Immunology, University of São Paulo, São Paulo 05508-900, Brazil

6 Department of Clinical Medicine, Medical School, University of São Paulo, Ribeirão Preto 14048-900, Brazil 


\section{Introduction}

Low-intensity laser irradiation is a common approach used for regenerative effects in cells and tissue on many in vitro and in vivo applications, especially to stimulate osteoblastic growth $[1,52,58]$ and neurons $[11,17,50$, 54] derived from mice. Concerning the benefits of laser light in medicine, two therapies have been broadly studied: Photodynamic Therapy (PDT) and Low-Level Laser Therapy (LLLT). The results of PDT dates from the $60 \mathrm{~s}$ when Lipson and Baldes [26] used haematoporphyrin derivative (HPD) as a photoactive compound. Since then, several studies have established PDT as a clinical protocol for the treatment of several oncological, dermatological, and ophthalmic diseases [2, 39]. The basic protocol can be defined as the administration of a nontoxic drug or dye, known as photosensitizer (PS) in a well-designed drug delivery system [42], followed by the illumination of the site with visible light, which, in presence of oxygen, generates cytotoxic species and consequently leads to cell death and tissue destruction.

In contrast to the reports of Mester [32], the PDT studies from Lipson and Baldes one decade later demonstrated that low-dose laser stimulation regenerates burns in rats, which led to numerous studies on LLLT as a photobiomodulation process for various medical applications, including wound repair [27], dermatological diseases [30], neurological damage [56], blood disorders [36], dentistry [10], pain and inflammation [61] as well as treatment of chronic skin ulcers [24]. Two mechanisms were suggested to be involved in the light-cell interactions. One is acceleration of electron transfer between redox pairs in some sections of the respiratory chain in the mitochondria [22]. The other is the production of small amounts of reactive oxygen species (ROS) induced by light absorption using cytochrome c oxidase to accelerate ATP production and cellular proliferation [38]. Recently, it has been proposed that photoactivation stimulates proliferation of dermal fibroblasts caused by ROS, which activate extracellular signal-regulated kinases (ERK) [19]. ERK contributes to the regulation of critical cell processes, including proliferation as well as differentiation, survival, and apoptosis. It has been suggested that fibroblast growth factor (FGF) stimulation leads to reactivation of ERK signalling [21]. In vitro studies have reported the use of light for biostimulation of fibroblast proliferation [39], osteoblast growth for bone remodelling [58] and 3D dermal equivalents [43], which support the expected outcomes for the proposed work.

The concept of nanotechnology was first described by Richard Feynman (1959, Nobel prize) to characterize the development of molecular machines that would have the capacity to control material properties at the nanoscale, i.e., components smaller than $100 \mathrm{~nm}$ in at least one dimension [60]. Since then, new drug delivery systems, such as liposomes, stealth liposomes, polymeric nanoparticles, dendrimers, nanocomposites and many others, have been developed and there has been an exponential increase in the appearance of new molecules or adaption of old molecules for new drug delivery systems (DDS) $[3,7,31,35,37]$. For this reason, nanomaterials could enhance delivery and treatment efficiency compared to conventional materials, and rapid progress in nanomedicine is expected $[43,60]$. As far as we know, there are no studies correlating in vitro data for low-intensity laser irradiation with nanodrug delivery systems. Thus, the aim of this study was to compare the photobiomodulation effects from visible light laser irradiation of nanostructured-forskolin (NF) to the free-form of the drug (forskolin, FF). For the nanostructured form, forskolin has been reported to induce up-regulation of neural genes and proteins due to its ability to stimulate the levels of cAMP, [46]. To do so, hMSCs derived from bone marrow were used as a source to examine possible enrichment of neuron-like cells in culture. An attribute of MSCs from bone marrow and adipose tissues among others can differentiate mesenchymal tissue in vitro, including osteocytes, chondrocytes and adipocytes [9, 45, 62].

MSCs are multipotent cells that are present in virtually all post-natal organs and human tissues [14], and they are located at the perivascular sites of different tissues [13, 14], which may indicate the existence of a systemic reservoir of multipotent progenitor cells [12].

In the past, Woodbury et al. [55] reported the unexpected capacity of adult human and rat MSCs derived from bone marrow to turn into neuron-like cells after various types of treatments. The cells expressed neural-specific proteins, including NSE (neuron-specific enolase), NF-M (neurofilament $\mathrm{N}$ ), and nestin, but the cells did not express GFAP (astrocyte marker, glial fibrillary acidic protein). Therefore, there is a notion that cultured MSCs are relatively homogeneous and could contain subgroups of cells with distinct properties that are composed of cells at different stages of commitment, self-renewal and have the capacity to express different gene products [34]. Additionally, the observation of a neural-like morphology considered to be a bona fide neuron continues to be the focus of intense debate [29].

In this study, we showed a significant improvement in $\beta$-tubulin III neural protein expression using visible lowintensity laser light irradiation $(650 \mathrm{~nm})$ alone or in association with e nanotechnology to design a drug delivery system for NF. This concept has been used worldwide with a positive response resulting from most attempts. The nanoparticles designed for NF was able to influence specific cytoskeleton neural protein expression in bone marrow 
hMSCs compared to the FF drug. We believe that these results are very promising and that this approach could be used for up-regulation of neural proteins and possibly other proteins related to hMSCs.

\section{Materials and Methods}

\section{Ethics Statement}

This study was approved by the Human Research Ethics Committee of the Faculty of Philosophy, Science and Letters, Department of Chemistry - University of São Paulo, Ribeirão Preto, and it was conducted according to the requirements of the Hospital Amaral de Carvalho (HAC, Jau, SP) and following the recommendations in the Declaration of Helsinki. Written informed consent was obtained from each donor. Human bone marrow samples were harvested from the iliac crest in allogeneic transplants from healthy adult subjects (permit number, 493.260).

\section{Isolation of hMSC}

Mononuclear cells (MNCs) were isolated from bone marrow. Briefly, the cells were separated using $1077 \mathrm{~g} / \mathrm{mL}$ of Ficoll-HyPaque $^{\mathrm{TM}}$ Plus (Histopaque-10177, GE HealthCare Bio-Sciences, Uppsala, Sweden). The density gradient was used in the isolation procedure to eliminate unwanted cell types that were present in the bone marrow aspirate. A small percentage (estimated approximately $0.01 \%$ ) of cells were isolated, attached and grown as fibroblast-like cells. Haematopoietic stem-cells (HSC) and non-adherent cells were removed when the medium was changed [41]. At this point, the cells were seeded in DMEM supplemented with $10 \%$ FCS (HyClone, Logan, UT, USA), $100 \mathrm{IU} / \mathrm{mL}$ of penicillin and $100 \mu \mathrm{g} / \mathrm{mL}$ of streptomycin (both Sigma, St Louis, MO, USA). After 2 weeks, the cells were detached with trypsin solution $(0.025 \%)$ and EDTA $(0.5 \mathrm{mM})$ (ScienCell, Carlsbad, CA, EUA) and were grown to approximately $85 \%$ confluence in a $37{ }^{\circ} \mathrm{C}$ humidified incubator with $5 \% \mathrm{CO}_{2}$. Bone marrow-derived-hMSC from 1 to 3 independent donors were used from the 3 rd to 5 th passages and analysed.

\section{Immunophenotyping}

Aliquots of $1.0 \times 10^{5}$ cells were harvested from the $3 \mathrm{rd}$ passage and centrifuged at 400x $g$ at room temperature for $10 \mathrm{~min}$. Afterwards, the cells were labelled with anti-human primary monoclonal antibodies conjugated with fluorochromes, including fluorescein isothiocyanate (FITC) or phycoerythrin (PE) according to the protocol described by the manufacturer (Becton Dickinson, San Jose, CA, USA). The antibodies that were used were CD13-PE, CD14-PE,
CD29-PE, CD31-FITC, CD34-PE, CD44-PE, CD45-FITC, CD49e-PE, CD51/61-FITC, CD54-PE, CD73-PE, CD90PE, CD105-PE, CD146-PE, HLA (class-I)-PE and HLADR (class-II)-FITC.

IgG1-FITC, IgG2a-PE, IgG1-PerCP (peridinin chlorophyll protein) and IgG-APC (allophycocyanin) (Becton Dickinson, San Jose, CA, USA) served as negative controls. Cells (10,000 events) were analysed in a FACScalibur flow cytometer (Becton-Dickinson, Mountain View, CA, USA). Data were acquired and analysed using the CELL Quest software (Becton-Dickinson, Mountain View, CA, USA).

\section{Nano-Forskolin Preparation}

Nanoemulsions (NE) were obtained with the spontaneous emulsification process described by Primo et al. (2008). Briefly, the organic phase was prepared containing phospholipids Epikuron® 170 (7.5\%) (Lucas Meyer, France/Aldrich, USA) in pure acetone at $55^{\circ} \mathrm{C}$. Forskolin (Sigma-Aldrich, USA) was previously dissolved in mineral oil Miglyol 812N (Stallergenes S.A., France) at a concentration of $20 \mu \mathrm{M}$, and it was added directly to the organic solution. Subsequently, this organic solution was slowly injected into an aqueous phase containing the biopolymer Pluronic F68 (Sigma-Aldrich, St Louis, MO, USA) (7.5\%) and mixed with magnetic stirring ( $300 \mathrm{rpm}$ for $20 \mathrm{~min}$ ) at $55^{\circ} \mathrm{C}$. Water was supplied with the E-Pure Barnstead D 3750 purification system. Final emulsification was obtained through rota-evaporation under reduced pressure at $65^{\circ} \mathrm{C}$ and pressure $<1 \mathrm{~atm}$. Nanoemulsions without the incorporation of forskolin were also prepared under the same conditions. All formulations were stored at $4{ }^{\circ} \mathrm{C}$ in the dark for 120 days.

\section{Free-Forskolin Treatment}

The cells were seeded in 6-well plates at a density of $1 \times 10^{6}$ cells/well in DMEM supplemented with $1 \%$ FCS (foetal calf serum), $100 \mathrm{IU} / \mathrm{mL}$ penicillin and $100 \mu \mathrm{g} / \mathrm{mL}$ of streptomycin in fresh culture medium containing $100 \mathrm{ng} / \mathrm{mL}$ bFGF (PeproTech, Rocky Hill, NJ) for 7 days. Afterwards, hMSC were incubated in culture medium and treated in the absence (MSCs control) or in the presence of $10 \mu \mathrm{M}$ free-forskolin (Sigma Chemical Co.) for up to 7 days. The cell cultures were incubated at $37^{\circ} \mathrm{C}$ with $5 \% \mathrm{CO}_{2}$ (Fig. 1).

\section{Nano-Forskolin Treatment}

The cells were seeded in 24-well plates at a density of $1 \times 10^{6}$ cells/well in DMEM supplemented with $1 \%$ FCS, $100 \mathrm{IU} / \mathrm{mL}$ penicillin and $100 \mu \mathrm{g} / \mathrm{mL}$ of streptomycin in fresh culture medium containing $100 \mathrm{ng} / \mathrm{mL}$ bFGF for 7 days. Afterwards, hMSC were incubated in culture medium and treated in the absence (control MSCs) or in 

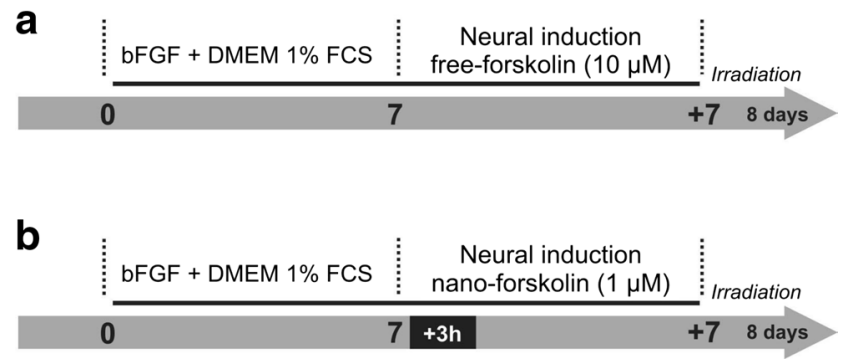

Fig. 1 Diagrams illustrating the neural induction protocols using 100 $\mathrm{ng} / \mathrm{mL}$ bFGF in DMEM containing a low concentration (1\%) of FCS for 7 days, followed by free-forskolin treatment for $10 \mu \mathrm{M}$ up to 7 days (a) and nanoforskolin for $3 \mathrm{~h}$ (b) up to 7 days. On the 8th day, the cells were subjected to low-level laser irradiation

Table 1 Low-level laser irradiation experimental setup

\begin{tabular}{llll}
\hline Light doses & $10 \mathrm{~mJ} / \mathrm{cm}^{2}$ & $20 \mathrm{~mJ} / \mathrm{cm}^{2}$ & $40 \mathrm{~mJ} / \mathrm{cm}^{2}$ \\
\hline Power (mW) & 50 & 50 & 50 \\
6/multiwell plates & 3.4 & 3.4 & 3.4 \\
$\quad$ diameter (cm) & & & \\
Irradiation time (s) & 8 & 15 & 30 \\
Energy (J) & 0.40 & 0.75 & 1.50 \\
Wavelength (nm) & 650 & 650 & 650 \\
\hline
\end{tabular}

Parameters for low-level laser irradiation were adjusted when using 24/multiwell (1.5 cm diameter) and 96/multiwell (0.6 cm diameter) plates

the presence of NF with the following concentrations: 0.5 ; $1.0 ; 5.0 ; 7.5$ and $10 \mu \mathrm{M}$ for $3 \mathrm{~h}$. After incubation, the cells were washed three times, and the volume was replaced with culture medium in each well. The cell cultures were incubated at $37^{\circ} \mathrm{C}$ with $5 \% \mathrm{CO}_{2}$.

\section{Photobiological Assays}

To investigate the potential effects of visible light on neural protein expression using light photobiomodulation with low-intensity laser light protocol alone or in association with FF and Nano-Forskolin, the hMSCs where treated as described above. For the photobiomodulation studies, fresh medium without phenol red was added, and the cells were irradiated with a diode Eagle laser (Quantum Tech, São Carlos, SP, Brazil). All the laser irradiation procedures were performed under the following conditions: a wavelength of $650 \mathrm{~nm}$, average power set to $50 \mathrm{~mW}$, and light irradiance at $5.5 \mathrm{~mW} \mathrm{~cm}$. Cells were exposed to light doses of 10,20 , and $40 \mathrm{~mJ} / \mathrm{cm}^{2}$. The parameters used in this study are shown in Table 1. After irradiation, the cells were maintained in medium culture at $37{ }^{\circ} \mathrm{C}$ in a humidified atmosphere of $5 \% \mathrm{CO}_{2}$ overnight. All the assays were carried out in triplicate.

\section{Cellular Viability}

\section{Flow Cytometry}

To assess viability, control and FF-treated hMSC $\left(1 \times 10^{5}\right.$ cells) were harvested after the last incubation and stained with $50 \mu \mathrm{g} / \mathrm{mL}$ propidium iodide $(50 \mathrm{mg} / \mathrm{mL}$ ) (DNA intercalating dye) (Sigma-Aldrich, St. Louis, MO, EUA). Cells (10.000 events) were then analysed in a FACSCalibur flow cytometer using an argon ion laser with an incident beam set at $488 \mathrm{~nm}$. Red fluorescence was analysed through a long pass filter set a $670 \mathrm{~nm}$. Data were acquired and analysed using Cell Quest software.

\section{MTT Assay}

The hMSCs were seeded at a density of $2 \times 10^{3}$ cells/well in a 96-well microplate and treated with NF at 0.5, 1.0, $2.5,5.0,7.5$ and $10 \mu \mathrm{M}$ for $3 \mathrm{~h}$ in culture medium containing $1 \%$ FCS. Afterwards, the cells were washed three times with PBS and maintained in culture medium at $37{ }^{\circ} \mathrm{C}$ in a humidified incubator with $5 \% \mathrm{CO}_{2}$ overnight. The control group was cultured in the absence of the drug. The cell viability was measured using MTT reagent (tetrazolium salt (3-[4,5-dimethylthiazol-2-yl]-2,5-dipheny tetrazolium bromide).

The MTT solution $(5.0 \mathrm{mg} / \mathrm{mL})$ was added to the MSCs at a proportion of $30 \mu \mathrm{g} / \mathrm{mL}$ to $170 \mu \mathrm{g} / \mathrm{mL}$ of culture medium (without FCS and phenol red) and then incubated in $5 \% \mathrm{CO}_{2}$ at $37{ }^{\circ} \mathrm{C}$ for $4 \mathrm{~h}$. After the final incubation, the medium was removed, and crystals formed due to the association between the mitochondrial dehydrogenases and the MTT reagent, which were dissolved with $200 \mu \mathrm{g} / \mathrm{mL}$ of 2-propanol. This colourimetric assay measures the reduction of the reagent with a compound named formazan by the action of mitochondrial dehydrogenases. The reduced formazan crystals were quantified using a spectrophotometer. The absorbance at 560 and $690 \mathrm{~nm}$ of each well was measured directly with a multiplate reader from Safire II (Tecan Trading AG, Mannedorf, Switzerland) to measure mitochondrial dehydrogenases and MTT, respectively, according to the mitochondrial activity of viable cells.

\section{Morphological Analysis}

\section{Phase-Contrast Microscopy}

The cells were observed daily using an inverted microscope (Olympus $1 \times 71$, Tokyo, Japan) and phase-contrast microscopy for morphological analysis. Photographic 
documentation was performed with a digital camera (Olympus UTVO 5XC-3, Tokyo, Japan).

\section{Immunofluorescence Assay}

Immunofluorescence was performed to detect neural markers. Control and treated hMSCs were seeded at a density of $1 \times 10^{4}$ cells/well on glass coverslips (GoldLab, Ribeirão Preto, SP, Brazil) in 24 well-microplates (CoStar, Corning, NY, USA), as described previously. The cells were fixed in $2 \%$ paraformaldehyde (Sigma, St Louis, MO, USA), for $10 \mathrm{~min}$ at room temperature. Both types of cells were washed three times with PBS and blocked with $0.1 \mathrm{M}$ glycine (Pharmacia Biotech, AB, USA) for $30 \mathrm{~min}$. Then, the cells were permeabilized with $0.3 \%$ Triton X-100 (Sigma-Aldrich, St. Louis, MO, USA) for $10 \mathrm{~min}$ at room temperature and blocked for $1 \mathrm{~h}$ with $1 \%$ bovine serum albumin (BSA) and $2 \%$ goat serum in PBS.

Samples were incubated with the primary antibodies anti-Nestin (Cat\#MAB5326, Millipore), and anti- $\beta$ tubulin III (Cat\#MAB1637, Millipore) separately at room temperature for $1 \mathrm{~h}$. The secondary antibody was the Alexa Fluor 488 mouse antibody (Cat\# A-21,202, Invitrogen, Carlsbad, CA, USA). Nuclei were stained with DAPI (4',6-diamidino-2-phenylindole) (Vysis, Des Plaines, IL, USA). Sections of human nerve were used as positive and negative controls. The negative control was incubated in the absence of primary antibodies.

Cells were visualized using a confocal laser scanning microscope (CLSM) (LSM 710; Carl Zeiss, OberKochen, Germany) with a $63 \times$ objective lens in immersion oil and an aperture of 1.4. An argon laser at $488 \mathrm{~nm}$ was used to excite secondary antibodies and emission was measured at $525 \mathrm{~nm}$. Visualization of the light scattering for each excitation wavelength was recorded in multitracking mode using separate detection channels. Image analysis was carried out using the ZEN 2008 software (Carl Zeiss). Control and test images were captured using identical settings.

\section{Quantitative Analysis}

Controls and treated hMSCs were seeded at a density of $1 \times 10^{3}$ cells/well in the 96-well microplates without coverslips (CoStar, Corning, NY, USA), as described above.

To perform quantitative analysis, the fluorescence intensity of the $\beta$-tubulin III was detected using High Content Imaging (INCell analyser 2200 system) and INCell investigator v.1.6.1 software (GE Healthcare Life Sciences, Upsala, Sweden). The system can remove cellular debris and background from the analyses.

\section{Western Blot Analysis}

Protein samples were extracted using RIPA buffer containing protease and a phosphatase inhibitor cocktail (Sigma, St. Louis, USA), centrifuged at $20.000 \mathrm{rpm}$ for $20 \mathrm{~min}$ at $4{ }^{\circ} \mathrm{C}$, and the protein concentration in the supernatant was determined with the Bradford method (Bio-Rad Lab, California, USA). A similar amount of total cell lysate was fractionated through 12\% SDS-PAGE and transferred to nitrocellulose membranes (Bio-Rad Lab, California, USA). The proteins transferred to the membrane were visualized by a $0.3 \%$ Ponceau solution stain for $5 \mathrm{~min}$. Later, the blots were blocked in TBS-T ( $50 \mathrm{mM}$ Tris, $\mathrm{pH}$ 8.0, $150 \mathrm{mM} \mathrm{NaCl}$, containing $0.1 \%$ Tween 20) and $5 \%$ non-fat dry milk. Immunodetection was performed with a monoclonal mouse antibody against $\beta$-tubulin III (similar to TUJ1) and nestin (Cat\#MAB5326, clone 10C2; Millipore). The first antibody recognizes the protein $\mathrm{C}$-terminal region (clone TU-20, Millipore, Temecula, CA.) (Cat\#MAB1637, Millipore). The membrane was incubated with an anti-IgG mouse secondary antibody conjugated with peroxidase (KPL Laboratories, Inc, USA). The bands of the immunoreactive polypeptides were detected by chemiluminescence using an ECL plus kit (Amersham Biosciences Co., Piscataway, NJ) according to the manufacturer's instructions (BioRad, Lab, California, USA). A molecular weight marker was used as a molecular mass standard. Purified swine brain tubulin was used as a positive control. Densitometric analyses of $\beta$-tubulin III bands of different groups were performed using ImageJ software developed by the National Institutes of Health (NIH).

\section{Statistical Analysis}

Experimental and control groups were conducted using oneway analysis of variance (ANOVA) followed by Tukey's post hoc test conducted with SAS® 9.2 software, Inc. (San Diego, CA, USA). The results are presented as the means $( \pm$ S.D.). The level of significance was 5\%. In Fig. 7, the box plot is one of the most common standard ways to evaluate and compare data distributions. The box indicates $50 \%$ of the data between the 25 th and 75 th percentiles, i.e., the lower and upper quartiles, and it draws focus to the centre of the distribution. The median, is represented by the line inside the box, and the mean is indicated by a spot. The vertical lines from the box represent the minimum and maximum values. The outliers are elements that do not comply with a given pattern in a set.

\section{Results}

\section{Immunophenotyping of hMSCs}

Analysis of the surface markers using flow cytometry showed that the cells exhibited hMSCs-specific markers, 
Table 2 Phenotypic profile of bone marrow hMSCs (3rd passage). The cells were incubated in DMEM containing 10\% FCS, labelled with conjugated antibodies against the indicated antigens $(C D$, cluster of differentiation) and analysed with flow cytometry. MSCs expressed specific markers, but did not express haematopoietic stem cell markers. The numbers represent the percentage of fluorescence intensity of the cells expressed by 3 distinct donors

\begin{tabular}{ll}
\hline Bone marrow & $\begin{array}{l}\text { Positive } \\
\text { cells } \\
(\%)\end{array}$ \\
\hline MSCs Markers & \\
Metalloproteínase & 92.9 \\
CD13 (aminopeptidase N) & \\
Integrins & 87.7 \\
CD29 ( $\beta 1$ chain) & 75.4 \\
CD49e ( $\alpha 5$ chain) & 94.1 \\
CD90 (Thy-1) & 75.1 \\
Receptors & 39.1 \\
CD44 (Hyaluronan receptor) & 80.1 \\
CD54 (ICAM-1) & 75.6 \\
CD73 (ecto5-nucleotidase) & \\
CD105 (endoglin) & 72.9 \\
MSCs /Endothelial & \\
CD166 & 59.5 \\
Constitutive & \\
HLA (class-I) &
\end{tabular}

Human isotype antibodies served as respective controls (BectonDickinson, San Jose, CA, USA)

including CD13, CD29, CD49e, CD90, CD44, CD54, CD73, CD105, CD166 and HLA (class-I) (Table 2). The haematopoietic stem cells markers CD14, CD34, CD45, CD31, CD51/61, CD106 and HLA-DR (class-II) were not expressed or had a small proportion of expression (Table 3).

\section{Dose-Response Effects of Low-Intensity Laser Irradiation on Cellular Viability in hMSCs}

Flow cytometry data showed that $89.3 \%( \pm 1.7)$ of control hMSCs $\left(0 \mathrm{~mJ} / \mathrm{cm}^{2}\right)$ were viable cells (Fig. 2a). After lowintensity laser irradiation with 10 and $40 \mathrm{~mJ} / \mathrm{cm}^{2}$ doses, there was a decrease in viable cells to $79.3 \%( \pm 2.4)$ and $78.8 \%( \pm 0.6)$, respectively. The hMSCs subjected to the $20 \mathrm{~mJ} / \mathrm{cm}^{2}$ dose maintained viable cells at $88.5 \%( \pm 0.9)$. The $20 \mathrm{~mJ} / \mathrm{cm}^{2}$ dose was considered the most efficient due to its satisfactory threshold for cell viability.

After treatment with $10 \mu \mathrm{M} \mathrm{FF}$, a reduction in the proportion of viable cells, $78.7 \%( \pm 3.7)$, was observed (Fig. 2b). After $10 \mu \mathrm{M}$ FF treatment plus low-intensity laser irradiation at the doses 10,20 , and $40 \mathrm{~mJ} / \mathrm{cm}^{2}$, there was not a statistically significant reduction $(P<0.05)$ in the percentage of viable cells (Fig. 2b). Taken together, these results showed that a dose of $20 \mathrm{~mJ} / \mathrm{cm}^{2}$ is the most likely dose to be used in
Table 3 Phenotypic profile of human bone marrow MSCs (3rd passage). The cells were incubated in DMEM containing 10\% FCS, labelled with antibodies against the indicated antigens (CD), and evaluated by flow cytometry. MSCs expressed low percentage or no expression of haematopoietic stem cell markers. The numbers represent the percentage of fluorescence intensity of the cells expressed by 3 distinct donors

\begin{tabular}{ll}
\hline Bone marrow & $\begin{array}{l}\text { Negative } \\
\text { cells }(\%)\end{array}$ \\
\hline Markers & \\
Hematopoietic & 0.3 \\
CD14 & 2.0 \\
CD34 & 2.0 \\
CD45 & \\
Endothelial & \\
(Adhesion molecule) & 0.3 \\
CD31 & 0.3 \\
CD51/61 & 2.2 \\
CD106 & \\
Constitutive & 3.0 \\
HLA DR (class-II) & \\
\hline
\end{tabular}

Human isotype antibodies served as respective controls (BectonDickinson, San Jose, CA, USA)
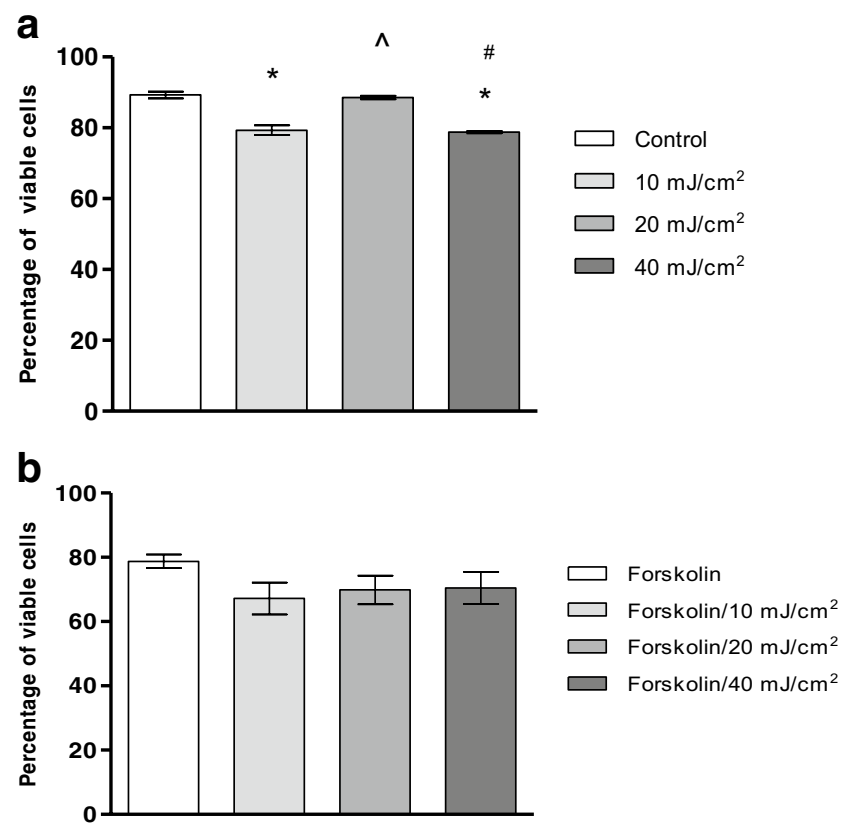

Fig. 2 Dose-response for the effects of low-intensity irradiation on cell viability in hMSCs. Cells were grown in DMEM supplemented with $1 \%$ FCS and $100 \mathrm{ng} / \mathrm{mL}$ of bFGF for 7 days. Afterwards, hMSCs were cultured in the absence (a) or presence (b) of $10 \mu \mathrm{M}$ free-forskolin (over the next 7 days). After treatment, hMSCs were irradiated at dosages of 0 (control), 10,20 and $40 \mathrm{~mJ} / \mathrm{cm}^{2}$. The viable cell was evaluated by flow cytometry. The percentages are presented as the mean \pm (S.D.) of triplicates from one donor. (*) $P<0.05$ in comparison with control, $\left({ }^{\wedge}\right) P<0.05$ in comparison with $10 \mathrm{~mJ} / \mathrm{cm}^{2}$; (\#) $\mathrm{P}<0.05$ in comparison with $20 \mathrm{~mJ} / \mathrm{cm}^{2}$, which was evaluated by one-way ANOVA followed by Tukey's post hoc test 
studies of the photobiostimulation process. In the Photobiomodulation process, investigators should always look for a better balance between the dose of light that is applied, the quantity of photons produced and absorbed in a biological effect, and take steps to avoid big changes in cell viability that could trigger other cellular responses.

\section{Dose-Response Effects of NF on the Cellular Viability of hMSCs and Morphological Evaluation}

The MTT assay was performed to evaluate the cell viability of NF at various concentrations. Control hMSCs showed $100 \%( \pm 0.05)$ viable cells (Fig. 3a). After treatment at concentrations of 0.5 and $1.0 \mu \mathrm{M}$, it was possible to maintain the number of viable cells at approximately $88.7 \%( \pm 10.7)$ and $88.8 \%$ ( \pm 11.4 ), respectively (Fig. 3a), which indicated that a dose of up to $1.0 \mu \mathrm{M}$ is satisfactory for the conservation of cellular viability. Then, all experiments using NF were conducted with this dose $(1.0 \mu \mathrm{M})$. hMSCs treated with $2.5 \mu \mathrm{M}$ $\mathrm{NF}$ showed a reduction in the proportion of viable cells to 48.4\% ( \pm 6.0$)(P<0.05)$ (Fig. 3a).

Phase-contrast microscopy of hMSCs treated with $1 \mu \mathrm{M}$ NF showed an increase in the proportion of adherent cells (Fig. 3b), but we did not observe neuron-like alterations. In contrast, the $10 \mu \mathrm{M}$ NF induced a decrease in the percentage of adherent cells and acquired a phenotype resembling neurons, which suggested that a subset of hMSCs can alter their phenotype in response to the stimuli, although the proportion of these cells was low (Fig. 3c).

As shown in Fig. 4, the incubation of hMSCs with $10 \mu \mathrm{M}$ FF exhibited neural-like morphology after 3 days (Fig. 4b) and 4 days (Fig. 4c, d), and the cells were morphologically distinct from the undifferentiated hMSCs (Fig. 4a). We noticed that the appearance of some cells reverted to a fibroblast-like morphology at the end of the treatment, i.e., up to 7 days post-drug treatment (data not shown). After 8 days, hMSCs were subjected only to low-intensity irradiation $\left(20 \mathrm{~mJ} / \mathrm{cm}^{2}\right)$ (Fig. 4e) and $10 \mu \mathrm{M} \mathrm{FF}$ treatment plus $20 \mathrm{~mJ} /$ $\mathrm{cm}^{2}$ irradiation did not appear to have an altered neuron-like morphology (Fig. 4f).

\section{Detection of a $\beta$-tubulin III Neural Marker by Immunofluorescence}

After 8 days, the $\beta$-tubulin III expression was observed in control MSCs (Fig. 5a) and in cells treated only with lowlevel laser irradiation $\left(20 \mathrm{~mJ} / \mathrm{cm}^{2}\right)$ (Fig. 5 b), treated with $10 \mu \mathrm{M} \mathrm{FF}$ (Fig. 5c), or treated with $10 \mu \mathrm{M}$ FF plus $20 \mathrm{~mJ} /$ $\mathrm{cm}^{2}$ laser irradiation (Fig. 5d).

The $\beta$-tubulin III expression was also observed after 8 days in control MSCs (Fig. 6a) and in cells treated only with low-level laser irradiation $\left(20 \mathrm{~mJ} / \mathrm{cm}^{2}\right)$ (Fig. 6b) or
Fig. 3 Dose-response of NF on cell viability in hMSCs (a). Cells were grown in DMEM medium supplemented with $1 \%$ FCS in the absence (control) or presence of the drug at the concentrations indicated. The viable cells were evaluated by an MTT assay. Percentages are presented as the mean \pm (S.D.) of a minimum six determinations from two distinct donors. (*) $P<0.05$ compared to the control as evaluated by one-way ANOVA with Tukey's post hoc test. (b) and (c): hMSCs were observed under a phase-contrast microscope. After treatment with $1 \mathrm{fM} \mathrm{NF}$, the adherent cell growth was superior (b) than the observed in cells treated with $10 \mathrm{fM}$. These data suggest that in response to the 10 IM stimulus, although in low proportion, there was a neuronlike phenotype (in the middle of figure) (c)

Fig. 4 Effects of the freeforskolin $(10 \mu \mathrm{M})$ on the morphology of hMSCs analysed under phase-contrast microscopy. (a) hMSCs exhibited a spindle-shaped morphology after 3 days. After treatment, hMSCs displayed a neuron-like morphology (arrow) after 3 days (b) and 4 days (c) and (d), high magnification). After 8 days, hMSCs submitted only to low-intensity irradiation $(20 \mathrm{~mJ} /$ $\mathrm{cm}^{2}$ ) and $10 \mu \mathrm{M}$ free-forskolin treatment combined with lowintensity irradiation $(20 \mathrm{~mJ} /$ $\left.\mathrm{cm}^{2}\right)(\mathbf{e})$ and (f) respectively did not develop a neuronal morphology
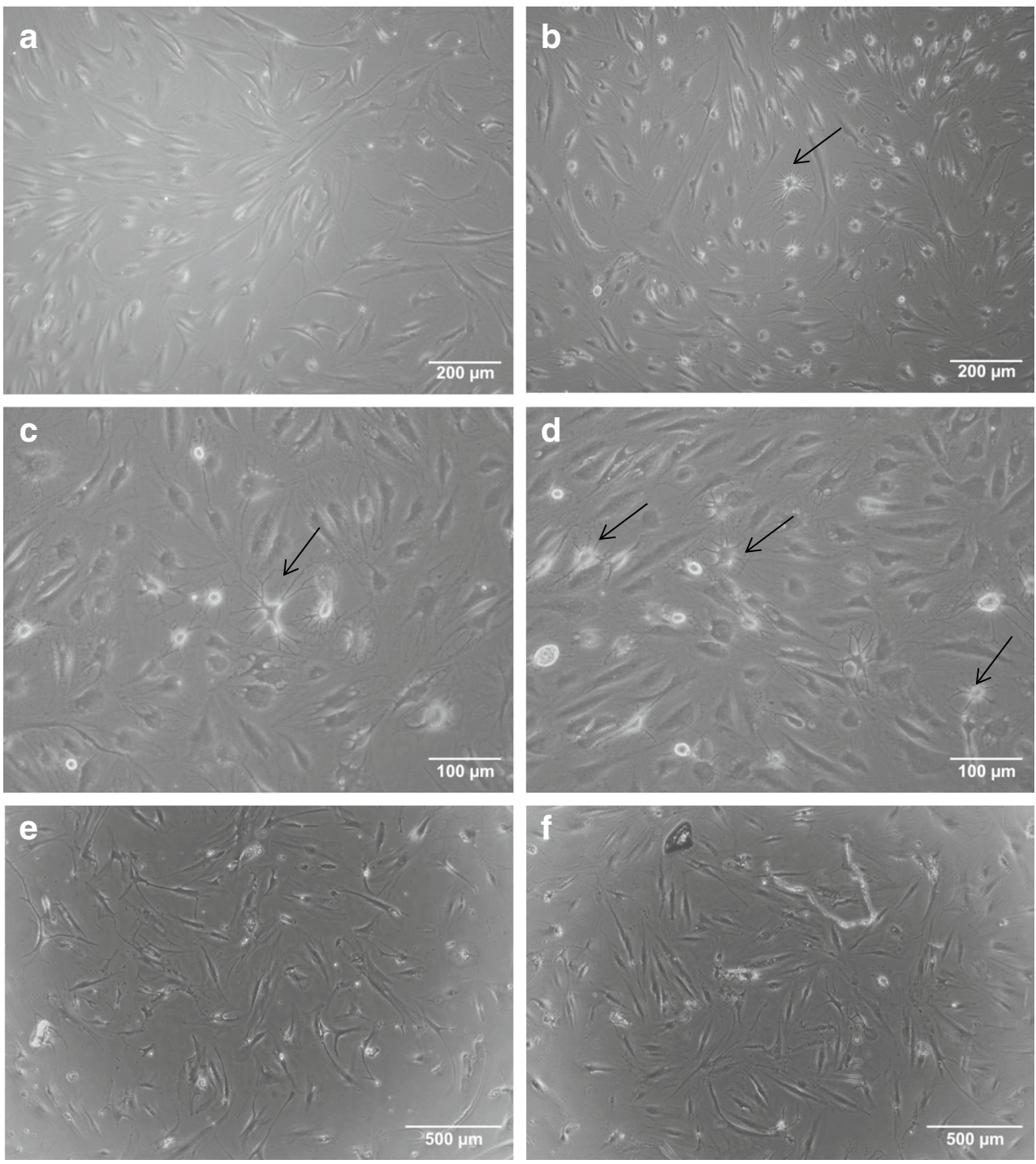

with $1.0 \mu \mathrm{M} \mathrm{NF}$ (Fig. 6c). The treatment with $1.0 \mu \mathrm{M} \mathrm{NF}$ plus $20 \mathrm{~mJ} / \mathrm{cm}^{2}$ laser irradiation seems to be more effective for inducing phenotypic changes because the cells had a neuron-like morphology with a well-defined body cell and longer processes (Fig. 6d) compared to other groups. $\beta$-tubulin III was detected in human nerve sections that were used as positive and negative controls (Fig. 6e, f). No nestin expression was detected in all eight groups. The cells were analysed using scanning laser confocal microscopy.

\section{Quantitative Analysis of Fluorescence Intensity for $\beta$-tubulin III Expression by High Content Imaging}

Data from the box plots graphs showed that after exposure using a low-power laser, there was a tendency to increase the $\beta$-tubulin III expression in all groups. Notably, the photobiostimulation process was greater in the irradiated nanoforskolin group [INF]: $4.4( \pm 1.4)$ compared to non-irradiated free-forskolin control cells [NFFC]: $3.1( \pm 0.5), P<0.05$. The effect of irradiation on nanoforskolin control cells [INC]: $4.9( \pm 0.9)$ was more pronounced compared to nonirradiated nanoforskolin [NNF]: $3.5( \pm 0.5)$ and non-irradiated free-forskolin $[\mathrm{NFF}] 3.6( \pm 0.6), P<0.05$. However, the weak increase observed in irradiated nanoforskolin control cells [INC]: $4.9( \pm 0.9)$ was not statistically significant compared to the increase for the irradiated nanoforskolin group [INF]: 4.4 ( \pm 1.4$) P>0.05$ (Fig. 7).

\section{Western Blot}

A Western blot confirmed the expression of $\beta$-tubulin III (55 kDa) (Fig. 8), which was increased in non-irradiated and irradiated control MSCs corresponding to the FF and NF treatments. However, we observed that there was downregulation of $\beta$-tubulin III in the presence of the free-form drug, which suggested there was a transient effect on the 
Fig. $5 \beta$-tubulin III protein (green) was detected by immunofluorescence in hMSCs. After 8 days, control MSCs (a) and after treatment groups: with only laser irradiation $(20 \mathrm{~mJ} /$ $\left.\mathrm{cm}^{2}\right)(\mathbf{b}), 10 \mu \mathrm{M}$ FF (c), $10 \mu \mathrm{M}$ FF plus laser irradiation $(20 \mathrm{~mJ} /$ $\left.\mathrm{cm}^{2}\right)(\mathbf{d})$. Nuclei were stained with DAPI (blue). Cells were analyzed using scanning laser confocal microscopy
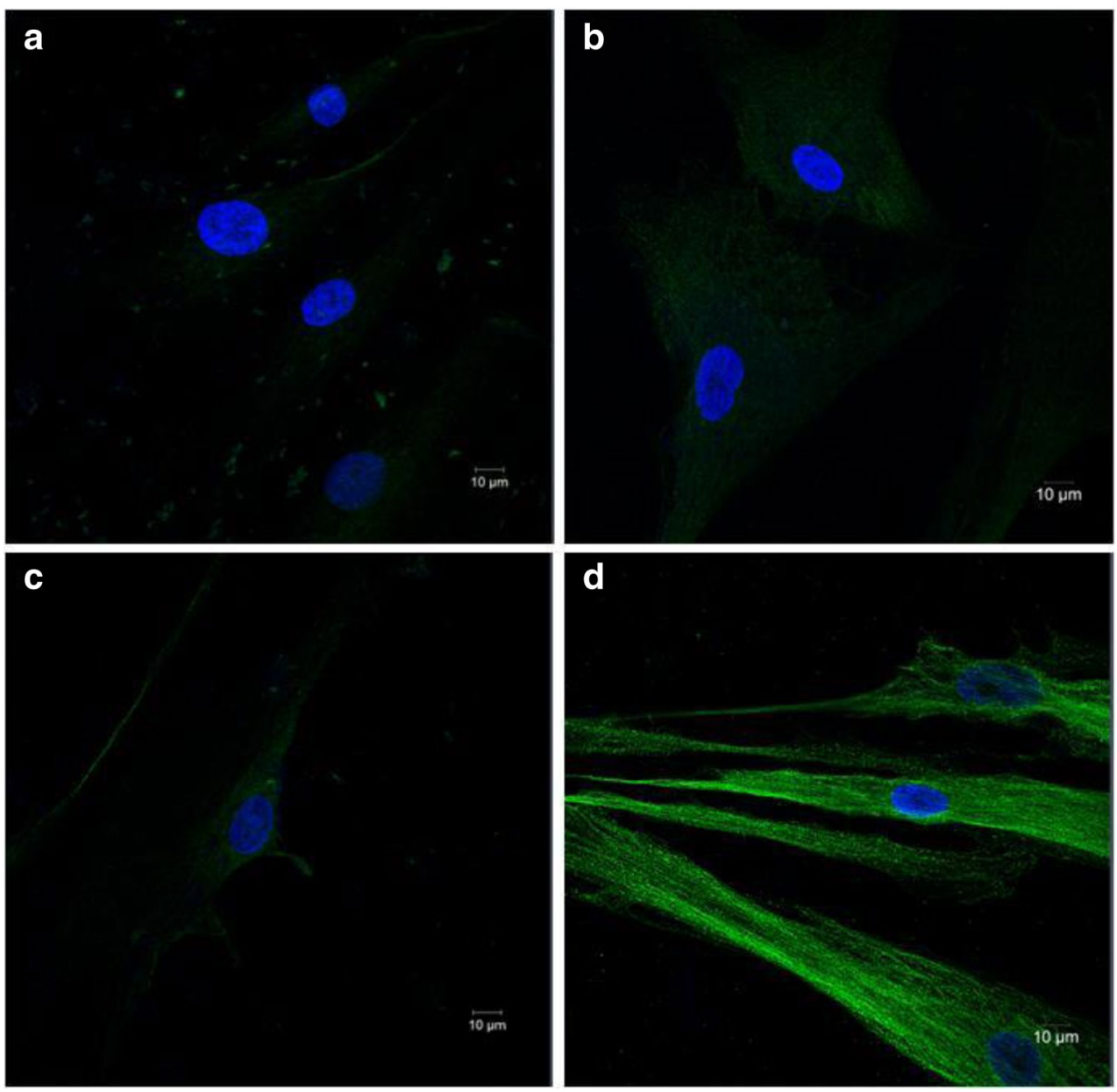

expression of this protein. As expected, after NF treatment, there was an improvement in the drug delivery system. An increase in the neural protein was observed after densitometric analysis of the bands. INF was the most effective (105\%) compared to IFF (53\%), and in non-irradiated cells, the NNF (102\%) was most effective compared to FF (68.2\%). Interestingly, the levels of protein were $68.2 \%$ for FF versus $53 \%$ for FFI (Fig. 8). In contrast, the nanodrug was able to maintain levels of protein similar to the controls (100\% and 99\%).

It is noteworthy that the dose used for NF was ten times smaller $(1.0 \mu \mathrm{M})$ compared to FF $(10 \mu \mathrm{M})$ and had a shorter incubation time, i.e., $3 \mathrm{~h}$ versus 7 days for FF. Although, the final incubation time in culture was the same for all groups.

\section{Discussion}

In the present study, we were interested in inducing up-regulation of neural proteins to eventually generate cells with a neuron-like lineage. To accomplish this goal, low-level laser irradiation and drug delivery systems were used. The data showed that the flow-cytometry analyses were consistent with previous studies [41], which confirmed that the cells used in this study are MSCs. Our data showed a trend in the improvement of $\beta$-tubulin III marker expression, which is a member of the microtubule family, after low-level laser irradiation in all groups. Neurobiology researchers found that the phosphorylated form of this protein is neuron-specific, and it is detected during early brain development and is down-regulated in adulthood [20]. Tubulin consists of an $\alpha / \beta$ heterodimer, and each of these peptides exists in different isoforms [28].

Importantly, in this study, the FF responsiveness to $\beta$-tubulin III down-regulation could be related to the increase in cAMP levels, which could have occurred in a fast, potent, but reversible pathway [49]. In fact, Rooney et al. [46] showed that in rat bone marrow MSCs, FF induced a sixfold increase in $\beta$-tubulin III expression after $6 \mathrm{~h}$ of exposure time, which was followed by alterations in morphology. However, this effect was transient because the cells reverted to their normal morphology in $24 \mathrm{~h}$.

Despite this evidence, we believe that long-term culture is fundamental to our understanding of $\beta$-tubulin III downregulation after FF treatment. The differences observed in 
Fig. $6 \beta$-tubulin III protein (green) was detected by immunofluorescence in hMSCs. After 8 days, control MSCs (a) and treatment groups with only laser irradiation $\left(20 \mathrm{~mJ} / \mathrm{cm}^{2}\right)(\mathbf{b})$, $10 \mu \mathrm{M}$ FF (c), and $10 \mu \mathrm{M} \mathrm{FF}$ plus laser irradiation $(20 \mathrm{~mJ} /$ $\mathrm{cm}^{2}$ ) showed cells resembling neuronal morphology with neuron-like cell bodies and longer processes compared to other groups (d). Human nerve sections were used as positive controls and as negative controls (suppressing the primary antibody) (e) and (f). Nuclei were stained with DAPI (blue). Cells were analysed using scanning laser confocal microscopy
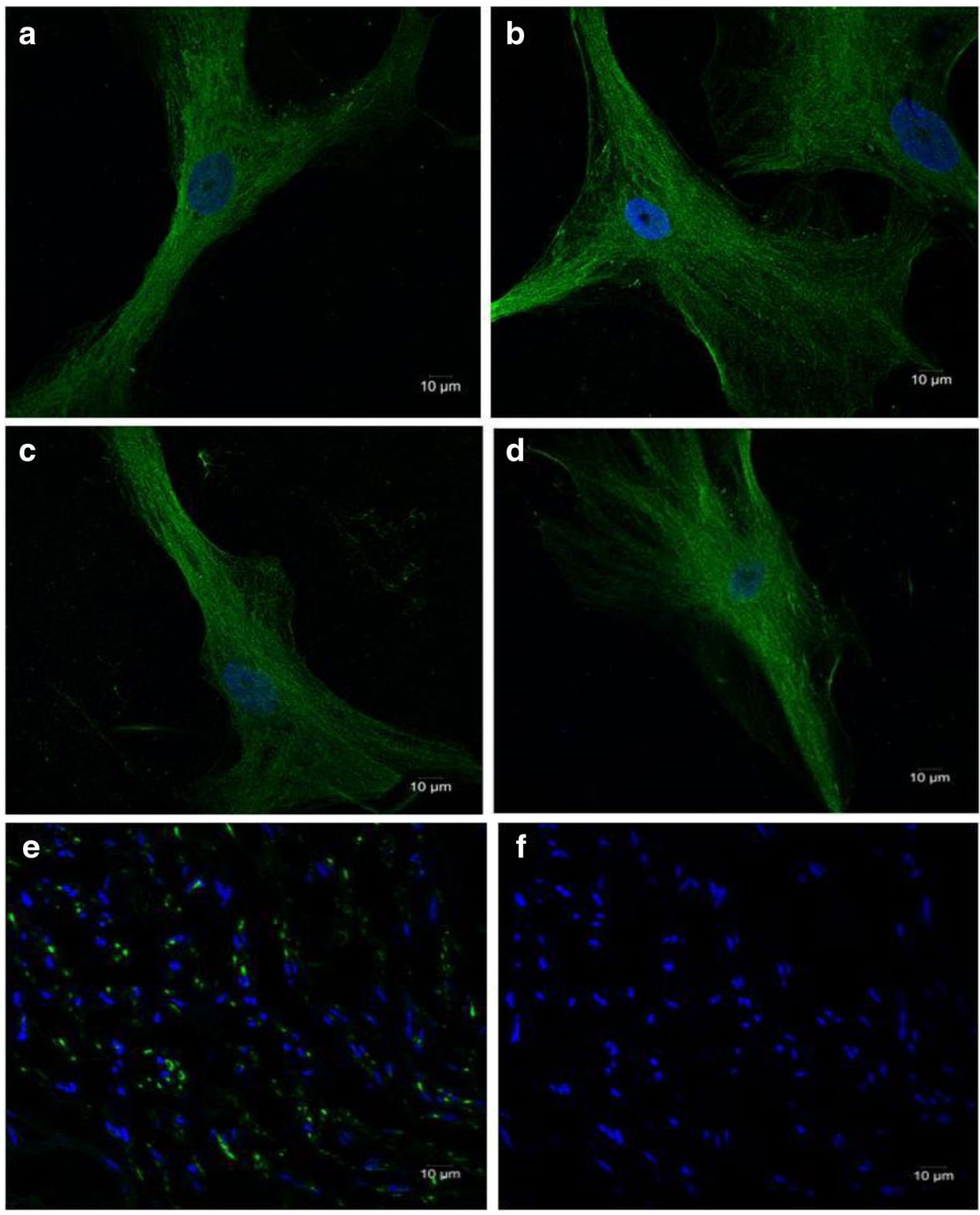

the mechanism of action for the drug may be related both to the origin tissue and to species, i.e., intrinsic genetic differences between mice and human beings.

Jang et al. [18] used a long-term culture protocol for neural enrichment for 14 days (bFGF for 7 days and FF for up to 7 days) using adipose tissue-derived hMSCs. The immunofluorescence results showed expression of $\beta$-tubulin III, GFAP and nestin, among other neural markers. Therefore, the authors demonstrated the efficiency of the protocol, which resulted in functional neurons according to patch clamp tests [18]. This outcome could be related to tissue specificity. In our study, we still do not know if the cells exhibit functional properties, so electrophysiological evaluation by patch clamp technique might be required in a future study.
Notably, our study showed that low-level laser irradiation exposure for control hMSCs (corresponding to the nanodrug group) has a photobiostimulatory effect, which indicates that irradiated cells present potential for $\beta$-tubulin III up-regulation. These results, at least in part, agree with the results of Yu et al. [57], who reported enhanced release of bFGF in cultured 3T3 fibroblasts (mouse embryo) after irradiation with a $660-\mathrm{nm}$ laser at a dose of $2.16 \mathrm{~J} / \mathrm{cm}^{2}$. The laser photobiostimulation effect appears to be dependent on the wavelength and on the energy level delivered to the cells. Studies indicated that this effect occurs between 0.05 and $10 \mathrm{~J} / \mathrm{cm}^{2}$ and has an effect on DNA synthesis, protein (collagen) and cell proliferation [57].

Therefore, we could speculate that in our system, i.e., laser irradiation exposure on hMSCs with $660 \mathrm{~nm}$ and at a 


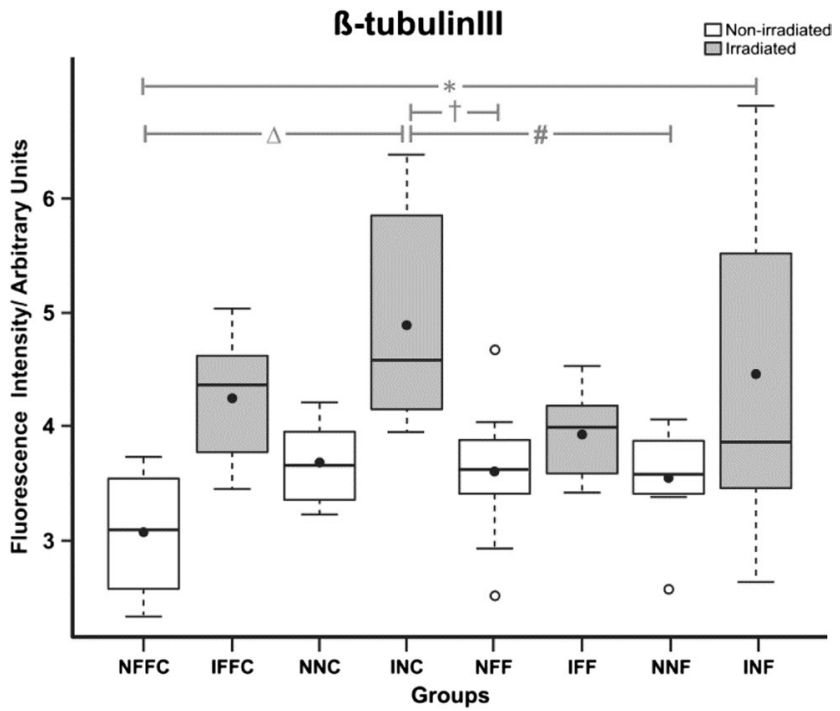

Fig.7 Quantification of fluorescence intensity for ß-tubulin III expression. The intensity was measured as arbitrary units using the INCell Analyzer System 2200. Values are presented as the average number of cells/plate $[\mathrm{n}=8$, mean \pm (S.D.) $]$. The symbols $*, \dagger, \Delta$, \# were used to indicate statistically significant differences. One-way ANOVA with the Tukey's post hoc test was used to compare all pairs of groups. $P<0.05$ was considered significant. Abbreviations: NFFC: non-irradiated free forskolin control cells, IFFC: irradiated free-forskolin control cells, NFF: non-irradiated free-forskolin treated cells, IFF: irradiated free-forskolin treated cells, NNFC: non-irradiated nanoforskolin control cells, INFC: irradiated nanoforskolin control cells, NNFC: nonirradiated nanoforskolin control cells and INFC: irradiated nanoforskolin-treated cells

dose of $20 \mathrm{~mJ} / \mathrm{cm}^{2}$ could induce a possible release of bFGF in cell culture and could increase the effect on $\beta$-tubulin III synergistically compared to non-irradiated control cells (i.e., the free-form drug group, FF). This evidence would also explain the minor effect observed compared to the NF group subjected to laser irradiation (FNI), in which bFGF release could compete with the drug compared to control cells (CNI).
Additionally, Tondreau et al. reported that naive MSCs express neuronal and glial proteins before responding to differentiation signals, and they have increased expression under appropriate stimuli.

We also found the glial protein GFAP in hMSCs, which developed structures similar to neurite outgrowth after NF treatment, which suggested a neural phenotype was enriched (data not shown).

Furthermore, the establishment of culture systems that do not depend on the FCS addition is very desirable due to reduction of the risk of contamination by xenogeneic agents and using culture cells in human cell therapy.

In this work, we argue that the use of irradiation along with nanotechnology (NF) could be a better approach for neural protein induction due to the maintenance of $\beta$-tubulin III levels compared to NFFC and FF, which showed signs of down-regulation. More importantly, NF was used at a lower concentration $(1 \mu \mathrm{M})$ versus $(10 \mu \mathrm{M} F \mathrm{~F})$ and had a shorter incubation time ( $3 \mathrm{~h}$ versus 7 days for $\mathrm{FF}$ ) although the overall time in culture was the same for all groups. Immunofluorescence results and Western blot results indicate that increased $\beta$-tubulin III expression was not merely a consequence of an increase in antigenic levels per relative unit. This concept was previously discussed by Kingham et al. [53] in their studies on glial proteins.

In our investigation, nestin was not observed. Nestin, which is an intermediate filament protein, was first reported in neuroepithelial neuronal precursor stem cells, and its expression decreases with neuronal maturation [25]. It is known that nestin expression is also detected in different cell types in the nervous system as well as in other tissues, such as skeletal muscle [6, 25] and heart tissue [6].

Woodbury et al. [55] demonstrated high levels of nestin expression at $5 \mathrm{~h}$ and 1-day post-treatment, but there was a decrease after 6 days in a subset of neuron-like derived rat MSCs, which indicated there was cellular maturation during this time.

There are several studies showing in vitro enrichment of MSCs towards neuronal and/or glial fates using different

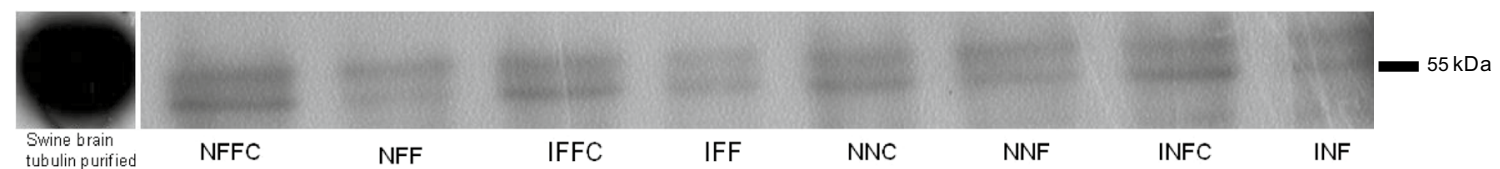

Fig. 8 Expression of the $\beta$-tubulin III protein was detected by Western Blot in hMSCs. Densitometric analysis of the bands for $\beta$-III tubulin revelead that the levels of protein were $100 \%$ in NFFC versus $68.2 \%$ in IFFC $(10 \mathrm{mM})$ (both in the absence of low-intensity irradiation). After the exposure in to low-level irradiation, percentage was maintained in about $99 \%$ (IFFC) versus 53\% after treatment of IFFC $(10 \mathrm{mM})$. In the nano-drug treatment, levels of protein were $100 \%$ (NNFC) versus $102 \%$ of NF $(1 \mathrm{mM})$, both in the absence of irradiation. After the exposure of the cells to the irradiation $\left(20 \mathrm{~mJ} / \mathrm{cm}^{2}\right)$, percentage of control MSCs was maintained at 99\% (INFC) versus $105 \%$ after treatment of INFC $(1 \mathrm{mM})$. Abbreviations: NFFC: nonirradiated free forskolin control cells, NFF: non-irradiated free-forskolin treated cells, IFFC: irradiated free-forskolin control cells, IFF: irradiated free-forskolin treated cells, NNFC: non-irradiated nano-forskolin control cells, NNF: non-irradiated nano-forskolin cells, INFC: irradiated nano-forskolin control cells and INF: irradiated nano-forskolin treated cells 
culture conditions. The protocols typically involve induction with chemical agents. For instance, supplemented media with cytokine cocktails: EGF (epidermal growth factor), BDNF (brain-derived neurotrophic factor), and bFGF concomitant or not with other drugs, such as alltrans-retinoic acid [47], $\beta$-mercaptoethanol (BME) and butylated hydroxyanisole [55], BME followed by retinoic acid and forskolin [16], forskolin [8] or bFGF plus forskolin [18, 29].

Additionally, Arthur et al. [4] used retinoic acid for neural induction and reported that human adult dental pulp stem cells (DPSCs) acquired a neuron-like morphology (bipolar and stellate form) and expressed the neural markers nestin and $\alpha$-tubulin III (at both the mRNA and protein levels). Furthermore, the cells produced a sodium current that was enhanced after stimulation, which indicated there were functional properties.

Currently, it is known that pluripotent stem cells treated with retinoic acid (a metabolic compound derived from vitamin A) undergo neurogenesis in vitro, which leads to increased aneuploidy and micronuclei generation. This fact should be accurately considered before employing in vitro neural derived-pluripotent stem cells in cellular therapy [48].

In summary, culture-expanded adult hMSCs under lowlevel laser irradiation conditions demonstrated photobiostimulation effects on $\beta$-tubulin III neuronal protein. To the best of our knowledge, this is the first report considering the combination of irradiation and nanotechnology for improving protein expression related to neuronal-like phenotypes in vitro. We believe that these methods could be used for the enrichment of proteins related to hMSCs. Furthermore, basic science studies provide a better understanding of drug delivery systems that will be crucial to support cell-therapy protocols in the future.

\begin{abstract}
Acknowledgements The authors are grateful to Hospital Amaral de Carvalho (Jau, São Paulo) and are especially grateful to Drs Antônio Cesarino Mota and Vergílio Rensi Colturato for providing bone marrow samples from donors as well as Nayara Rezende for help with the nanoforskolin and Sandra Navarro Brescian for artwork. I want to thank Fernanda Udinal for language advice and Priscilla Carnavale Gomes Ferreira for reviewing the manuscript. Valéria Ferreira-Silva is grateful for a postdoctoral fellowship from Coordenacão de Aperfeicoamento de Pessoal de Nível Superior (CAPES). This work was supported by Financiadora de Estudos e Projetos (FINEP 01.10.0758.01), CEFAPUSP (São Paulo), Instituto Nacional de Ciência e Tecnologia, CélulaTronco e Terapia Celular (INCTC), Conselho Nacional de Desenvolvimento Científico e Tecnológico (CNPq), and Fundação de Amparo à Pesquisa do Estado de São Paulo (FAPESP\# 2013/50181-1), Brazil.
\end{abstract}

\section{Compliance with Ethical Standards}

Competing Interests The authors have no potential conflicts of interest to report.

\section{References}

1. Abramovitch-Gottlib, L., Gross, T., Naveh, D., et al. (2005). Low level laser irradiation stimulates osteogenic phenotype of mesenchymal stem cells seeded on a three-dimensional biomatrix. Lasers in Medical Science, 20(3-4), 138-146.

2. Agostinis, P., Berg, K., Cengel, K. A., et al. (2011). Photodynamic therapy of cancer: an update. CA Cancer Journal for Clinicians., 61(4), 250-281.

3. Allen, T. M., \& Cullis, P. R. (2013). Liposomal drug delivery systems: from concept to clinical applications. Advanced Drug Delivery Reviews, 65(1), 36-48.

4. Arthur, A., Rychkov, G., Shi, S., Koblar, S. A., \& Gronthos, S. (2008). Adult human dental pulp stem cells differentiate toward functionally active neurons under appropriate environmental cues. Stem Cells, 26(7), 1787-1795.

5. Beavo, J. A., \& Brunton, L. L. (2002). Cyclic nucleotide researchstill exponding after half a century. Nature Reviews, 3(9), 710-718.

6. Berry, S. E., Andruszkiewicz, P., Chun, J. L., \& Hong, J. (2013). Nestin expression in end-stage disease in dystrophin-deficient heart: implications for regeneration from endogenous cardiac stem cells. Stem Cells Translational Medicine, 2(11), 848-861.

7. Bose, S., \& Tarafder, S. (2012). Calcium phosphate ceramic systems in growth factor and drug delivery for bone tissue engineering: a review. Acta Biomaterialia, 8(4), 1401-1421.

8. Caddick, J., Kingham, P. J., Gardiner, N. J., Wiberg, M., \& Terenghi, G. (2006). Phenotypic and functional characteristic of MSCs differentiated along a Schwann cell lineage. Glia, 54(8), 840-849.

9. Caplan, A. I., \& Bruder, S. P. (2001). Mesenchymal stem cells: building blocks for molecular medicine in the 21 st century. Trends Molecular Medicine, 7(6), 259-264.

10. Carrol, J. D., Milward, M. R., Cooper, P. R., Hadis, M., \& Palin, W. M. (2014). Developments in low level light therapy (LLLT) for dentistry. Dental Materials, 30(5), 465-475.

11. Cavalcanti, M. F., Maria, D. A., de Isla, N., et al. (2015). Evaluation of the proliferative effects induced by low-level laser therapy in bone marrow stem cell culture. Photomedicine Laser Surgery, 33(12), 610-616.

12. Corseli, M., Chen, C. W., Sun, B., Yap, S., Rubin, J. P., \& Péault, B. (2012). The tunica adventitia of human arteries and veins as a source of MSCs. Stem Cells Development, 21(8), 1299-1308.

13. Covas, D. T., Panepucci, R. A., Fontes, A. M., et al. (2008). Multipotent mesenchymal stromal cells obtained from diverse human tissues share functional properties and gene-expression profile with $\mathrm{CD} 146^{+}$perivascular cells and fibroblasts. Experimental Hematology, 36(5), 642-654.

14. da Silva Meirelles, L., Chagastelles, P. C., \& Nardi, N. B. (2006). Mesenchymal stem cells reside in virtually all post-natal organs and tissues. Journal of Cell Science, 119(11), 2204-2213.

15. Dezawa, M., Kanno, H., Hoshino, M., et al. (2004). Specific induction of neuronal cells from bone marrow stromal cells and application for autologous transplantation. Journal of Clinical Investigation, 113(12), 1701-1710.

16. Dezawa, M., Takahashi, I., Esaki, M., Takano, M., \& Sawada, H. (2001). Sciatic nerve regeneration in rats induced by transplantation of in vitro differentiated bone-marrow stromal cells. European Journal of Neuroscience, 14(11), 1771-1776.

17. Ginani, F., Soares, D. M., Barreto, M. P., \& Barbosa, C. A. (2015). Effect of low-level laser therapy on mesenchymal stem cell proliferation: a systematic review. Lasers in Medical Science, 30(8), 2189-2194.

18. Jang, S., Cho, H. H., Cho, Y. B., Park, J. S., \& Jeong, H. S. (2010). Functional neural differentiation of human adipose 
tissue-derived stem cells using bFGF and forskolin. Biomed Central Cell Biology, 11(25), 1-13.

19. Jang, Y. H., Koo, G. B., Kim, J. Y., Kim, Y. S., \& Kim, Y. C. (2013). Prolonged Activation of ERK Contributes to the Photorejuvenation Effect in photodynamic therapy in human dermal fibroblasts. Journal of Investigative Dermatology, 133(9), 2265-2275.

20. Jiang, Y. Q., \& Oblinge, M. M. (1992). Differential regulation of $\beta_{\text {III }}$ and other tubulin genes during peripheral and central neuron development. Journal Cell Science, 103(3), 643-651.

21. Joo, D., Woo, J. S., Cho, K. H., Han, S. H., Min, T. S., Yang, D. S., Yun, C. H., et al. (2016). Biphasic activation of extracellular signal-regulated kinase (ERK) $1 / 2$ in epidermal growth factor (EGF)-stimulated SW480 colorectal cancer cells. Biochemistry Molecular Biology Reports, 49(4), 220-225.

22. Karu, T. I., \& Kolyakov, S. F. (2005). Exact action spectra for cellular responses relevant to phototherapy. Photomedicine and Laser Surgery, 23(4), 355-361.

23. Kingham, P. J., Kalbermatten, D. F., Mahay, D., Armstrong, S. J., Wiberg, M., \& Terenghi, G. (2007). Adipose-derived stem cells differentiate into a Schwann cell phenotype and promote neurite outgrowth in vitro. Experimental Neurology, 207(2), 267-274.

24. Lei, X., Liu, B., Huang, Z., \& Wu, J. (2015). A clinical study of photodynamic therapy for chronic skin ulcers in lower limbs infected with Pseudomonas aeruginosa. Archives of Dermatological Research, 307(1), 49-55.

25. Lendahl, U., Zimmerman, L. B., \& Mckay, R. D. G. (1990). CNS stem cells express a new class of intermediate filament protein. Cell, 60(4), 585-595.

26. Lipson, R. L., Baldes, E. J., \& Olsen, A. M. (1961). Use of a derivative of hematoporphyrin in tumor detection. Journal of the National Cancer Institute, 26(1), 1-11.

27. Loreti, E. H., Pascoal, V. L., Nogueira, B. V., Silva, I. V., \& Pedrosa, D. F. (2015). Use of laser therapy in the healing process: A literature review. Photomedicine and Laser Surgery, 33(2), 104-116.

28. Ludueña, R. F. (1997). Multiple forms of tubulin: different gene products and covalent modification. International Review of Cytology, 178, 207-275.

29. Maltman, D. J., Hardy, S. A., \& Przyborski, S. A. (2011). Role of mesenchymal stem cells in neurogenesis and nervous systems repair. Neurochemistry International, 59(3), 347-356.

30. Mamalis, A. D., Lev-Tov, H., Nguyen, D. H., \& Jaqdeo, J. R. (2014). Laser and light-based treatment of Keloids - a review. Journal of the European Academy of Dermatology and Venereology, 28(6), 689-699.

31. Merino, S., Martín, C., Kostarelos, K., Prato, M., \& Vázquez, E. (2015). Nanocomposite Hydrogels: 3D Polymer Nanoparticle Synergies for On-Demand Drug Delivery. American Chemistry Society Nano, 9(5), 4686-4697.

32. Mester, E., Spiry, T., Szende, B., Spiry, F., \& Sacher, A. (1971). Effect of laser rays on wound healing. The American Journal of Surgery, 122(4), 532-535.

33. Mignani, S., Kazzouli, E., Bousmina, S., Majoral, M., JP (2013). Expand classical drug administration ways by emerging routes using dendrimer drug delivery systems: A concise overview. Advanced Drug Delivery Review, 65(10), 1316-1330.

34. Minguell, J. J., Fierro, F. A., Epunã, M. J., Erices, A. A., \& Sierralta, W. D. (2005). Nonstimulated human uncommitted mesenchymal stem cell express cell markers of mesenchymal and neural lineages. Stem Cells Development, 14(4), 408-414.

35. Mura, S., Nicolas, J., \& Couvreur, P. (2013). Stimuli-responsive nanocarriers for drug delivery. Nature Materials, 12(11), 991-1003.

36. Nadur-Andrade, N., Barbosa, A. M., Carlos, F. P., Lima, C. J., Coqo, J. C., \& Zamuner, S. R. (2012). Effects of photobiostimulation on edema and hemorrhage induced by Bothrops moojeni venom. Lasers in Medical Science, 27(1), 65-70.

37. Panyam, J., \& Labhasetwar, V. (2003). Biodegradable nanoparticles for drug and gene delivery to cells and tissue. Advanced Drug Delivery Review; 55(3), 329-347.

38. Passarella, S., \& Karu, T. (2014). Absorption of monochromatic and narrow band radiation in the visible and near IR by both mitochondrial and non-mitochondrial photoacceptors results in photobiomodulation. Journal of Photochemistry and Photobiology, 140, 344-358.

39. Peplow, P. V., Chung, T. Y., \& Baxter, G. D. (2012). Photodynamic modulation of wound healing: a review of human and animal studies. Photomedicine and Laser Surgery, 30(3), 118-148.

40. Phinney, D. G., \& Prockop, D. J. (2007). Concise review: mesenchymal stem/multipotent stromal cells: the state of transdifferentiation and modes of tissue repair - current views. Stem Cells, 25(11), 2896-2902.

41. Pittenger, M. F., Mackay, A. M., Beck, S. C., et al. (1999) Multilineage potential of adult human mesenchymal stem cells. Science, 284(5411), $143-47$.

42. Primo, F. L., Siqueira-Moura, M. P., Simioni, A. R., \& Tedesco, A. C. (2007). Preparation, characterization and cytotoxicity assays of chloroaluminum phthalocyanine photosensitizer drug loaded in PLGA-nanocapsules. Drugs Future, 32, 74.

43. Primo, F. L., Reis, M. B. D., Porcionatto, M. A., \& Tedesco, A. C. (2011). In Vitro Evaluation of chloroaluminum phthalocyanine nanoemulsion and low-level laser therapy on human skin dermal equivalents and bone marrow mesenchymal stem cells. Current Medicinal Chemistry, 18(22), 3376-3381.

44. Primo, F. L., Bentley, M. V. L. B., \& Tedesco, A. C. (2008). Photophysical studies and in vitro skin permeation/retention of Foscan ${ }^{\circledR} /$ Nanoemulsion (NE) applicable to photodynamic therapy skin cancer treatment. Journal of Nanoscience and Nanotechnology, 8(1), 340-347.

45. Prockop, D. J. (1997). Marrow stromal cells as stem cells for nonhematopoietic tissues. Science, 276(5309), 71-74.

46. Rooney, G. E., Howard, L., O`Brien, T., Windebank, A. J., \& Barry, F. P. (2009) Elevation of cAMP in mesenchymal stem cells transiently up regulates neural markers rather than inducing neural differentiation. Stem Cells Development, 18(3), 387 - 98.

47. Sanchez-Ramos, J., Song, S., Cardozo-Pelaez, F., et al. (2000). Adult bone marrow stromal cells differentiate into neural cells in vitro. Experimental Neurology, 164(2), 247-256.

48. Sartore, R. C., Campos, P. B., Trujillo, C. A., et al. (2011). Retinoic acid-treated pluripotent stem cells undergoing neurogenesis present increased aneuploidy and micronuclei formation. PLoS One, 6(6), 1-10.

49. Seamon, K. B., Padgett, W., \& Daly, J. W. (1981) Forskolin: Unique diterpene activator of adenylate cyclase in membranes and in intact cells. Proceedings of the National Academy of Sciences of United States of America, 78(6), 3363-3367.

50. Sharma, S. K., Kharkwal, G. B., \& Sago, M. (2011). Dose response effects of $810 \mathrm{~nm}$ laser light on mouse primary cortical neurons. Laser Surgery Medicine, 43(8), 851-859.

51. Stein, A., Benayahu, D., Maltz, L., \& Oron, U. (2005). Low-Level Laser Irradiation Promotes Proliferation and Differentiation of Human Osteoblasts in Vitro. Photomedicine and Laser Surgery, 23(2), 161-166.

52. Stein, E., Koehn, J., Sutter, W., et al. (2009). Phenothiazine chloride and soft laser light have a biostimulatory effect on human osteoblastic cells. Photomedicine and Laser Surgery, 27(1), 71-77.

53. Tondreau, T., Lagneaux, L., Dejeneffe, M., et al. (2004). Bonemarrow-derived mesenchymal stem cells already express specific neural proteins before any differentiation. Differentiation, 72(7), 319-326. 
54. Wong-Riley, M. T., Liang, H. L., Eells, J. T., et al. (2005). Photobiomodulation directly benefits primary neurons functionally inactivated by toxins: role of cytochrome c oxidase. The Journal of Biological Chemistry, 280(6), 4761-4771.

55. Woodbury, D., Schwarz, E. J., Prockop, D. J., \& Black, I. B. (2000). Adult rat and human bone marrow stromal cells differentiate into neurons. Journal of Neuroscience Research, 61(4), 364-370.

56. Wu, Q., Xuan, W., Ando, T., et al. (2012). Low-level laser therapy for closed-head traumatic brain injury in mice: effect of different wavelengths. Lasers in Surgery and Medicine, 44(3), 218-226.

57. Yu, W., Naim, J. O., \& Lanzafame, R. J. (1994). The effect of laser irradiation on the release of bFGF from 3T3 fibroblasts. Photochemistry and Photobiology, 59(2), 167-170.

58. Zancanela, D. C., Primo, F. L., Rosa, A. L., Ciacanglini, P., \& Tedesco, A. C. (2011). The Effect of Photosensitizer Drugs and
Light Stimulation on Osteoblast Growth. Photomedicine and Laser Surgery, 29(10), 699-705.

59. Zhang, G., Zeng, X., \& Li, P. (2013). Nanomaterials in cancertherapy drug delivery systems. Journal of Biomedical Nanotechnology, 9(5), 741-750.

60. Zhang, L., \& Webster, T. J. (2009). Nanotechnology and nanomaterials: promises for improved tissue regeneration. Nanotoday, 4(1), 66-80.

61. Zhang, Y., Song, S. P., Fong, C. C., Tsang, C. H., Yang, Z., \& Yang, M. (2003). cDNA microarray analysis of gene expression profiles in human fibroblast cells irradiated with red light. Journal of Investigative Dermatology, 120(5), 849-857.

62. Zuk, P. A., Zhu, M., Ashjian, P., et al. (2002) Human adipose tissue is a source of multipotent stem cells. Molecular Biology of the Cell, 13(12), 4279-4295. 